\title{
PARADIGMA BARU MENGEMAS DAKWAH MELALUI MEDIA TELEVISI DI ERA GLOBALISASI
}

\author{
Fatmawati
}

"Penulis adalah dosen Fakultas Dakwah dan Komunikasi UIN Syarif Hidayatullah Jakarta.

Abstract. In this global era, do'wah through television has an important role in human development, especially akhlaq, moral, and character development. At present, television should deliver da'wah programs with a new paradigm adopting 5 basic elements. 1) as the centre of information for all social classes, 2) as a media of education and instruction, which participate in socializing religious values so that it can promote the bith of intellectual and religious Muslim society khoiru ummah); 3) da'wah package with direct or indirect interactive methods with ddi or da'iyah can give a fast and appropriate solution to the society; 4) the existence of actual and creative do'wah programs on $I V$ can balance the uneducative programs, especially foreign cuttures which come into society without any boundaries; 5) television can be a means of economic and social development among Muslims through producing marketable dowwah programs, such as talk show, religious drama program (sinetron), Islamic movies, etc. and this can be the source of financial funding for Islamic preaching. Keywords: globalization, television, marketable, talk show, interactive.

\section{PENDAHULUAN}

Televisi biasa dilihat sebagai media yang memiliki kekuatan untuk mempengaruhi khalayak. Pandangan ini dapat terjerumus menjadi dasar bagi komunikasi yang bersifat top down, baik yang diselenggarakan oleh institusi negara maupun oleh masyarakat. Di sini, komunikasi merupakan upaya mengubah sasaran bertujuan untuk menanamkan nilai, ideologi, atau gagasan yang dipandang penting dan luhur oleh komunikator. "Pengubahan" itu dapat berupa pendidikan, propaganda, dan sosialisasi, yang semuanya bersifat satu arah.

Perkembangan besar selanjutnya terjadi saat ditemukannya alat-alat digital. Proses cetak-mencetak dan kirim-mengirim informasi kembali mengalami kemajuan super pesat, mesin-mesin yang dulunya sebagian besar oleh manusia diganti oleh mesin-mesin yang bisa "bekerja sendiri”, hasil yang dicapai pun lebih banyak, efektif serta efisien. Ribuan lembar dapat dicetak dalam hitungan menit, bahkan detik. Seiring dengan itu, terjadi pula kemajuan di bidang penyebaran informasi. Saat ini, tidak asing lagi kalau ada mesin yang bisa mencetakjarakjauh sepertimesin fax, disusul oleh pengiriman informasi lewat mayantara (dunia maya), jutaan informasi bisa ditransfer hanya dalam hitungan detik melalui media televisi dan internet. Jangkauannya pun semakin meluas ke seluruh dunia dengan cepat. Informasi yang dikirim bisa diakses dan disaksikan dalam waktu sekejap mata di seluruh penjuru bumi oleh siapa pun.

Sejak bergulirnya reformasi pada tahun 1998, wajah media berubah total. Dalam konteks pengemasan program acara wajah media televisi menjadi lebih vulgar, lebih terbuka, dan sangat informatif di semua program acara. Sebuah fenomena yang di Orde Baru sangat sulit untuk diperoleh, kecuali pada media bawah tanah (underground). Dengan demikian, keleluasaan pengemasan dakwah di televisi pun semakin bervariasi dan menarik untuk dikembangkan dalam rangka menjaga eksistensi dakwah di televisi Indonesia.

Di satu sisi, fenomena di atas mencuatkan harapan besar bagi Islam sebagai agama yang menjunjung tinggi penghayatan nilai-nilai kebenaran universal. Ledakan informasi bisa dijadikan medium penyampaian dan penyebar nilai-nilai Islam ke khalayak luas. Masyarakat pun sudah bergerak dari sekadar masyarakat mendengar menjadi masyarakat membaca, bahkan menjadi sangat kritis. Masyarakat tidak lagi mengenal dan menganut satu nilai, mereka bisa memilih dan menilai, dan pada 


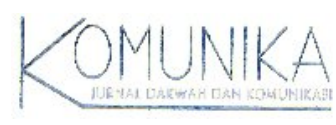

akhirnya menentukan sikap untuk menerima dan meninggalkan apa yang menurut mereka sesuai keinginannya atau tidak sesuai keinginannya. Pada titik ini, yang menjadi pertanyaan kemudian adalah apakah masyarakat yang menentukan posisi nilai tawar dakwah atau dakwah yang menggiring masyarakat pada pilihan yang seharusnya mereka terima? Tentu saja, semuanya tidak berlangsung sederhana, ledakan media yang tidak terbendung menjadi kiblat pembentukan nilai, dan itu harus direspon secara arif dan bijaksana, terlebih bagi praktisi dakwah.

Sebagai pusat informasi, hiburan, pendidikan, serta pengajaran, televisi diakui telah menyumbangkan peran yang besar dalam ikut serta mencerdaskan bangsa, khususnya pada tayangan yang memuat nilai pendidikan dan agama di era globalisasi ini. Keberadaan tayangan dakwah di media televisi dirasakan makin penting dan diharapkan dapat menjawab dan merespon berbagai persoalan yang timbul di masyarakat. Sejak krisis nasional melanda negeri ini juga dunia internasional, berbagai persoalan timbul dalam masyarakat, di antaranya; Pertama, problem teologis dalam bentuk ateisme (praktis), politeisme, dan okultisme. ${ }^{1}$ Kedua, problem moral mulai dari penyalahgunaan wewenang, korupsi yang makin meluas, tindakan kriminal, kemaksiatan hingga pelanggaran norma-norma kesusilaan. Ketiga, problem kejiwaan (psikologis) dalam bentuk dislokasi, yaitu perasaan tidak mendapat tempat dalam masyarakat, disorientasi merupakan perasaan tidak mampu dan tidak mengetahui arah dan masa depan yang akan dilalui, dan disharmoni, yaitu perasaan putus asa yang dapat mengganggu keseimbangan seseorang (hopeless). ${ }^{2}$

Syekh Ali Mahfudz, ulama dan pemikir dakwah terkemuka, memandang bahwa salah satu faktor yang dirasakan mengancam eksistensi manusia modern di era globalisasi ini adalah rusaknya fitrah yang menyebabkan manusia suka pada kebathilan (al-bathil) dan benci pada kebenaran (al-haqq). Oleh karena fitrah telah rusak, maka jangan heran jika manusia memandang kebaikan sebagai keburukan, dan sebaliknya, keburukan dipandang sebagai kebaikan. Bahkan, ada sebagian orang dengan sengaja dan bangga mempertontonkan dosa-dosa dan kejahatannya tanpa rasa malu sedikit pun. ${ }^{3}$

Berbagai problem di atas perlu direspon dan dicari solusi pemecahannya. Hal ini adalah agenda program dakwah yang amat penting pada era globalisasi ini. Ulama, dä, dan daïah harus bekerjasama dengan pihak stasiun televisi untuk mengemas dakwah semenarik mungkin dan mampu memberi solusi pada permasalahan umat, tentu dengan melakukan pembaharuan dalam kemasan, metode, konsep dakwah, serta peningkatan kualitas dai dan daiah. Oleh karena itu, acara dakwah yang ditonton dan dimaknai masyarakat bukan kemasan dakwah yang menjenuhkan dan ditinggalkan oleh umat.

\section{TELEVISI SEBAGAI MEDIA MASSA ELEKTRONIK}

Everet M. Rogers, dalam bukunya Communication Technology, yang ditandai dengan empat era teknologi di dunia sebagai pengaruh dari revolusi fisika yang melahirkan revolusi komunikasi tahapan itu ditandai dengan: (1) Era komunikasi tulisan (the writing era of communication). Era ini dimulai tahun 4000 SM pada waktu bangsa Sumeria menggunakan tablet dari tanah liat dan bangsa Cina, dan ketika itu menemukan tulisan untuk mencetak buku; (2) Era percetakan (the printing era of commumication). Era ini dimulai dengan ditemukannya alat percetakan oleh Guttenberg pada tahun 1456 (cetakan pertama Kitab Injil). Kemudian pada tahun 1833, dimulainya sirkulasi media massa the New York sym sebagai Penny Press Newspaper, dan tahun 1839 dimulai adanya fhotografi dengan metode praktis dalam surat kabar; (3) Era telekomunikasi (telecommunication era). Dalam era ini, antara lain tercatat Samul Morse pada tahun 1844 untuk pertama kalinya mengirim pesan secara telegraf. Pada tahun 1976 Allexander Graham Bell untuk pertama kalinya mengirim pesan secara teleponis. Kemudian, telekomunikasi ini berkembang pesat dengan dilakukannya pengiriman pesan lewat radio dan pada tahun 1920 dimulainya radio siaran yang dilanjutkan dengan penemuan televisi yang didemonstrasikan pada tahun 1933; (4) Era komunikasi interaktif (interactive communication era). Era komunikasi ini dimulai dari ditemukannya komputer yang diberi nama Main Frame Computer, ENIAC pada tahun 1946 di Universitas Pennsylvania. Dalam era ini ditemukan pula transitor dan video vita pada tahun 1947 dan 1956 ditemukannya microprocessor dan sistem teleks pada tahun 1976, dan sejak tahun 1979 video teks menyempurnakan radio dan televisi sebagai produk teknologi elektronik canggih. ${ }^{4}$

Yang dimaksud dengan televisi adalah televisi siaran (television broadcast), yang merupakan media dari jaringan komunikasi yang berlangsung satu arah, komunikatornya melembaga, pesannya bersifat umum, sasarannya menimbulkan 


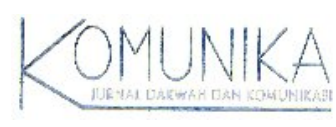

keserempakan, dan komunikannya heterogen. Hal tersebut perlu dijelaskan karena di samping televisi siaran terdapat juga televisi jenis lain di antaranya Closed Circuit Television (CCTV) atau Jaringan Televisi Sekitar yang sering dioperasikan di kampus-kampus atau tempat lain. Hal ini berbeda dengan televisi siaran yang sistem hubungannya antara pemancar dengan pesawat penerima tanpa kawat, maka pada CCTV kedua komponen jaringan tersebut dihubungkan dengan kabel koleksial, yakni untuk menyalurkan pesan-pesan dari studio CCTV. Di samping itu, ada pesan-pesan khusus, misalnya bahan kuliah yang komunikannya homogen, umpamanya mahasiswa.

Televisi memiliki karakter yang khas, wajahnya sebagai media hiburan dan jurnalisme mudah bercampur aduk. Secara institusional, stasiun televisi sejak awal dapat dibedakan dari karakter utamanya, yaitu intensi fungsional yang diembannya. ${ }^{5}$ Dikenal dua tipe orientasi penyiaran, yaitu televisi publik (public TV) dan televisi komersial (commercial TV).

Televisi publik sendiri di atas: Pertama, televisi pendidikan (Educational TV) yang difungsikan sebagai pendukung langsung untuk proses pendidikan seperti pengajaran/intruksional. Tipe stasiun televisi ini dapat dijabarkan sebagai subtitusi pelatih/instruktur yang mengajar warga masyarakat untuk mencapai tingkat kemahiran teknis yang dapat digunakan dalam kehidupan sosialnya. Kedua, adalah televisi publik yang berfungsi sebagai institusi, yang menjalankan fungsi pendidikan sosial. Stasiun ini dimaksudkan sebagai perpanjangan dari lembaga masyarakat yang berupaya mendidik warga masyarakat agar lebih mengapresiasi kehidupan dalam konteks norma sosial berupa kehidupan keagamaan atau idealisme sosial yang menjadi acuan bagi kehidupan normatif. ${ }^{6}$

Sementara itu, televisi komersial (Commercial TV) mengembangkan fungsi hiburan dan jurnalisme. Stasiun ini hadir dengan menjual informasi fiksional dan faktual. Dalam kehadirannya ini, televisi sendiri merupakan industri yang memiliki sifat ekonomi (economical traits). Pada pihak lain, televisi komersial adalah faktor penting sebagai pendukung mekanisme ekonomi pasar?

Televisi merupakan paduan audio dari segi penyiarannya (broadcast) dan video dari segi gambar bergeraknya (moving images). Para pemirsa menangkap siaran televisi karena ada prinsip-prinsip radio yang mentransmisikannya, dan melihat gambar-gambar yang bergerak dan hidup karena ada unsur-unsur film yang memvisualisasikannya. Televisi adalah paduan audio dan video. Istilah televisi terdiri dari kata "tele" yang berarti jauh dan "visi" (vision) yang berarti penglihatan dengan asumsi televisi jauhnya ditransmisikan dengan penglihatannya diwujudkan dengan prinsip-prinsip kamera sehingga menjadi gambar, baik dalam bentuk gambar hidup atau bergerak maupun gambar diam (still picture). ${ }^{8}$

Masa yang akan datang lebih banyak lagi produk-produk rekayasa teknologi media sebagai bagian dari konvergensi media menjadi bagian dari rekayasa sosioteknologi atau konstruksi sosial teknologi. Sosioteknologi adalah upaya menggabungkan dua pendekatan yang berbeda tentang teknologi, yaitu pendekatan sosiologikal dan pendekatan teknologikal menjadi sebuah pendekatan yang sama-sama mengkaji tentang kemanfaatan teknologi di masyarakat. Oleh karena itu, application of technology dan transfer of technology tidak lagi menjadi kepentingan para ahli teknologi namun juga menjadi kepentingan para ahli ilmu-ilmu sosial. Dengan kata lain, kedua persoalan ini menjadi persoalan sosial (umat) dan tidak saja persoalan teknologi.9

Ketika dunia ini telah dikuasai oleh manusia dengan menggunakan kemampuan teknologi telematika, maka tidak ada yang tidak mungkin terjadi. Manusia sepertinya menjadi setengah dari Tuhan, mereka semua berubah menurut kehendak manusia, sedangkan Tuhan hanya mengabulkan saja keinginan manusia. Manusia telah membuktikan kebenaran firman Allah bahwa manusia adalah khalifah di bumi, dan hal ini telah dibuktikan dengan kemapuan manusia menguasai teknologi telematika. ${ }^{10}$

Agaknya, televisilah media massa yang paling kontroversi dalam masyarakat. Di negara maju, manakala semakin langka orang pergi ke rumah ibadat, "gereja" dibangun melalui televisi, sejumlah pendeta menggunakan sarana televisi sebagai "gereja"-nya dan memperoleh jamaat ratusan ribu bahkan jutaan orang, hal yang mustahil diperoleh melalui paroki-paroki tradisional. Sementara itu, wajib belajar yang menjadi konsekuensi dari undang-undang di berbagai negara menyebabkan pemerintahnya harus meyediakan program pendidikan melalui televisi untuk warganya yang bermukim di wilayah udara bersalju dan terasing, jauh dari sarana persekolahan konvensional. Siaran via satelit dan Television Receive Only (TVRO) 


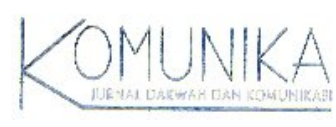

bukanlah kemewahan, tetapi kebutuhan primer bagi pemerintah atau masyarakat yang harus menjalankan undang-undang pendidikannya dengan mengantar program pendidikan ke setiap rumah di pelosok manapun karena televisi sepenuhnya menjadi sekolah."

Begitulah televisi publik dan pendidikan menjalankan fungsinya menggantikan lembaga sosial tradisional seperti gereja dan sekolah. Buah teknologi ini masuk ke dalam kehidupan rumah tangga menggantikan berbagai lembaga yang makin pudar peranannya atau memang tidak terjangkau akibat kendala fisik karena televisi bersifat komplementer. Oleh karena itu, sebagai pelaku dakwah perlu ekstra kreatif mengembangkan metode dan cara berdakwah dengan media televisi yang menjadi tontonan pokok setiap individu dan keluarga di Indonesia karena televisi bisa menjangkau sampai pelosok manapun dan dakwah yang dikemas menarik lewat televisi akan mengefektifkan dakwah lebih luas. Dakwah dan pendidikan lewat televisi sedang trend dan digandrungi masyarakat saat ini. Kalau pastur di gereja sudah memanfaatkan televisi sebagai media missionarisnya, maka mengapa para dai dan däiah hanya tenang-tenang saja menjadi penonton bukan pelaku/aktor. Padahal, umat Islam sangat menanti, dan haus pada dakwah dan pendidikan agama lewat televisi. Para daï dan daïah seharusnya peka dan tanggap dalam melihat fenomena yang ada agar tidak menjadi bulan-bulanan media televisi.

Suka tidak suka, media televisi sudah menjadi bagian kehidupan dalam keluarga. Tinggal sikap kita dalam menghadapinya, akan menjadikan sebagai komplemen ataukah alternatif. Kedua pilihan ini membawa konsekuensi yang berbeda, yang pertama akan menempatkannya sebagai bagian pelengkap saja dalam peranan sumber nilai sosial, sedang keduajika kita sudah kehilangan peranan sumber nilai konvensional dan televisi telah masuk menggantikannya.

\section{TELEVISI SEBAGAI MEDIA DAKWAH ERA GLOBALISASI}

Siaran televisi bukanlah sekadar tontonan, tetapi juga merupakan suatu kenyataan yang sering diuji secara ideologis dan normatif. Oleh karenanya, pengelola televisi tidak hanya melayani motif-motif psikologis yang lazim bagi dunia tontonan, tetapi juga harus memperhitungkan ideologi dan normayang dianut sebagian besar orang dalam masyarakat.

Televisi pada pokoknya mempunyai tiga fungsi, yakni penerangan, pendidikan, dan hiburan. Sebagai sub-sistem dari sistem negara dan pemerintah, di mana suatu stasiun televisi beroperasi, maka sifat penerangan, pendidikan, dan hiburan yang disiarkannya kepada masyarakat tergantung pada sistem negara dan pemerintah bersangkutan. Sifat penerangan, pendidikan, dan hiburan yang disiarkan televisi di negara liberal seperti Amerika Serikat berbeda dengan di negara komunis seperti Uni Sovyet, berbeda pula dengan negara yang berdasarkan pancasila seperti Indonesia. Maka dari itu, fungsi televisi secara umum adalah sebagai berikut:

a. Fungsi Penerangan (The Information Function) adalah siaran televisi sejak pertama kali diperkenalkan kepada masyarakat, yakni tahun 1946 di New York Amerika Serikat, ketika dimulainya Sidang Umum Perserikatan Bangsa-bangsa sudah melakukan fungsi penerangan dalam bentuk pemberitaan mengenai sidang amat penting seusainya Perang Dunia keII. Sejak itu, masyarakat Amerika dan kemudian masyarakat negara-negara lainnya menaruh perhatian besar kepada televisi siaran ini karena dianggap sebagai media yang mampu menyiarkan informasi yang amat memuaskan. Hal ini karena dua faktor yang terdapat pada media massa audio visual itu, pertama adalah faktor immediacy, yaitu langsung dan dekat dan kedua faktor realism yaitu kenyataan.

b. Fungsi Pendidikan (The Educational Function) adalah sebagai komunikasi massa. Televisi merupakan sarana yang ampuh untuk menyiarkan acara pendidikan kepada khalayak yang jumlahnya begitu banyak secara simultan, sesuai dengan makna pendidikan yakni meningkatkan pengetahuan dan penalaran masyarakat. Sistem televisi menyiarkan acara-acara tertentu secara teratur, misalnya, acara agama Islam, cerdas cermat dan lain-lain. Selain acara pendidikan yang dilakukan secara berkesinambungan seperti di atas, stasiun televisi juga menyiarkan berbagai acara yang secara implisit mengandung pendidikan seperti sandiwara, fragmen, ceramah dan lain sebagainya.

c. Fungsi Hiburan (The Entertainment Function) maksudnya adalah dikebanyakan negara terutama yang masyarakatnya bersifat agraris, fungsi hiburan yang melekat pada siaran televisi siaran tampaknya dominan. Sebagian besar dari alokasi waktu masa siaran di isi oleh acara-acara hiburan. Hal ini dapat dimengerti karena pada layar televisi dapat 


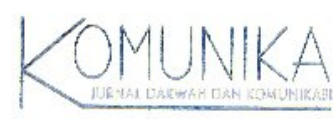

ditampilkan gambar hidup beserta suaranya bagaikan kenyataan (realism), dan dapat dinikmati di rumah oleh seluruh keluarga, juga dapat dinikmati khalayakyang tidak mengerti bahasa asing termasuktuna aksara. ${ }^{12}$

Tiga fungsi utama televisi di atas perlu dicermati oleh kaum akademisi khususnya insan-insan yang berkcipung di Fakultas Dakwah dan Komunikasi. Kecenderungan televisi menyita waktu, penggunaannya nyaris bersifat mutlak. Waktu yang terpakai untuk menonton televisi jauh lebih banyak dibandingkan dengan kegiatan penyerapan pengetahuan dan nilai lainnya.

Dengan demikian, sebagai institusi sosial, televisi telah melakukan panetrasi sehingga menggeser sumber-sumber nilai dan pendapat yang konvensional. Akibatnya, media ini dengan sendirinya menghadapi tekanan, terutama tekanan dari kalangan yang merasa berkepentingan untuk melindungi generasi yang masih harus mengalami proses sosialisasi nilai-nilai tradisional, seperti kebudayaan lokal dan agama. Tekanan dari berbagai institusi sosial lainnya berupa pengawasan media (media watch) dan kampanye penyadaran masyarakat terhadap unsur buruk dalam muatan media (media awareness), termasuk juga tekanan dari pelaku dakwah agar masyarakat tidak terjebak pada kemerosotan akhlak.13 Oleh karena itu, penilaian terhadap mata acara televisi perlu dicermati sama halnya mencermati isi program itu sendiri agar proporsional fungsi televisi dalam menyajikan program siarannya. Oleh karena itu, perlu mengemas acara dakwah yang menarik, solutif dan komunikatif melalui media televisi akan efektif untuk mempengaruhi umat ke arah nilai-nilai Islami.

\section{PARADIGMA BARU DAKWAH MELALUI MEDIA TELEVISI}

Istilah paradigma (paradigm) kini makin banyak dipergunakan. Thomas Kuhn adalah orang pertama yang mempopulerkan istilah ini. Paradigma sesungguhnya menunjuk pada suatu model, ${ }^{4}$ pola ideal,, 5 atau kerangka berfikir (konsep) yang pergunakan sebagai cara atau alat dalam memandang atau mengkaji suatu masalah. Paradigma biasanya berisi premis-premis teoritik (filosofis) dan juga metodologis. ${ }^{16}$

Sebuah paradigma baru digagas dan dicanangkan dimaksudkan untuk mengganti paradigma lama yang sudah usang atau tidak memadai lagi (out of date). Ketetapan ini juga berlaku bagi dakwah di media televisi. Paradigma baru program acara dakwah di media televisi menurut hemat penulis, harus memuat pembaharuan dalam kemasannya. Hal itu setidaknya menyangkut 4 (empat) hal pokok, yaitu pembaharuan menyangkut konsep dakwah, perluasan dan penguatan jaringan/kerjasama dengan lembaga-lembaga yang bergerak di bidang dakwah, penguatan dana primer dan sekunder untuk mendanai program dakwah, dan peningkatan kualitas dan kuantitas däi dan dåiah, khususnya yang sudah populer di media televisi.

Pengertian dakwah Islam adalah menyeru ke jalan Allah yang melibatkan unsur-unsur penyeru, pesan, media, metode yang diseru, dan Tuhan. Menurut al-Bahiy, dakwah Islam berarti merubah suatu situasi ke situasi yang lebih baik, sesuai ajaran Islam. ${ }^{77}$ Dalam dakwah terdapat dua dimensi besar: pertama, mencakup penyampaian pesan kebenaran, yaitu dimensi "kerisalahan" (bi ahsan al-qawl), merupakan tuntunan dari Q.S. al-Maidah: 67 dan Q.S al-Imran:104. Dimensi kerisalahan dakwah mencoba menumbuhkan kesadaran diri (individu/masyarakat) tentang kebenaran nilai dan pandangan hidup secara Islam, sehingga terjadi proses internalisasi nilai-nilai Islam sebagai nilai hidupnya, dengan kata lain dakwah kerisalahan dalam prakteknya merupakan proses mengkomunikasikan dan menginternalisasikan nilai-nilai Islam, dalam hal ini (a). Islam merupakan sumber nilai, dan (b). Dakwah sebagai proses alih nilai. Kedua, mencakup pengaplikasian nilai kebenaran yang merupakan "kerahmatan" (bi ahsan al-amal), mengacu pada firman Allah Q.S. al- Anbiya':107. Dakwah kerahmatan ini merupakan upaya mengaktualisasikan Islam sebagai rahmat (jalan hidup yang menyejahterakan, membahagiakan, dan sebagainya) dalam kehidupan umat manusia. Dengan begitu, kalau dalam dimensi kerisalahan dakwah lebih cocok sebagai "mengenalkan Islam", sedangkan dalam dimensi kerahmatan, dakwah merupakan upaya mewujudkan Islam dalam kehidupan. ${ }^{18}$

Selanjutnya, dari dimensi kerisalahan terdapat dua bidang besar, yaitu (1) $T a b l i g h h^{19}$ dan (2) Irsyad, ${ }^{20}$ sedangkan dalam dimensi kerahmatan terdapat dua bidang besar juga, yaitu (1) Tadbir ${ }^{\text {el }}$ dan (2) Tathwir. ${ }^{2}$ Salah satu di antara bidang dakwah kerisalahan adalah tabligh secara bahasa, yang berarti menyampaikan informasi atau berita (khabar). Dalam kelembagaan 


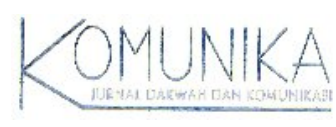

pendidikan tinggi dakwah Islam, kajian tentang ilmu dakwah adalah upaya mentransformasikan dan menginternalisasikan nilai-nilai Islam kepada umat yang sifatnya massal serta pendekatan keilmuannya pun komunikasi massa atau dakwah ummah.

Pertama, pembaharuan kemasan konsep dakwah di media televisi mengacu pada al-Qur'an dapat diidentifikasi sebagai panggilan (aktualisasi) iman (Q.S. al-Anfal/8:24), pencerahan agama (Q.S. Ibrahim/16:1 dan 5) dan proses masyarakat menuju kualitas "khairu ummah". Allah berfirman: Kamu adalah umat yang terbaik yang dilahirkan untuk mamusia, menyuruh kepada yang makruf, dan mencegah dari yang mungkar, dan beriman kepada Allah. Sekiramya ahli kitab beriman tentulah itu lebih baik bagi mereka, di antara mereka ada yang beriman dan kebanyakan mereka adalah orangorang fasik (Q.S. Ali-Imran/3:110). Dakwah, pada dasarnya, adalah usaha orang beriman untuk mewujudkan dalam semua aspek kehidupan, baik pada tataran individu, keluarga, masyarakat, umat, dan bangsa. Sebagai aktualisasi iman, dakwah merupakan keharusan dan menjadi tugas penting dan suci bagi setiap muslim, setingkat dengan kapasitas dan kapabilitas yang dimilikinya masing-masing.

Upaya mewujudkan iman dan Islam dapat dilakukan dengan berbagai cara, antara lain melalui komunikasi dan penerangan agama (al-tabligh wal al bayan), pembudayaan dan sosialisasi nilai-nilai Islam dalam kehidupan masyarakat (alamr bi al-mairuf), dan kontrol sosial terhadap segala bentuk kejahatan yang akan mengganggu dan merusak tatanan dan nilai-nilai Islam (al-nahy-u 'an al-Mungkar), keteladanan prilaku (qudwah hasanah), serta melalui pergerakan (harakah atau movement) dengan membangun organisasi yang kuat dan solid sebagai wadah bersama yang akan menghimpun dan memobilisasi kekuatan Islam untuk kemajuan dakwah.23

Dakwah sebagai usaha individu maupun kolektif melalui organisasi perlu mempertimbangkan dan memperhatikan keperluan dan kepentingan masyarakat yang menjadi objek atau sasaran dakwah (mad’u). Dengan demikian, dakwah yang disiarkan melalui media televisi harus berorientasi pada kepentingan dan kemajuan masyarakat, yang dalam ilmu dakwah dikenal dengan istilah "mad'u centred dakwah". Hal ini berarti dakwah melalui media televisi di era globalisasi ini haruslah merupakan ikhtiar yang sungguh-sungguh untuk memberikan "hidangan", yang benar-benar enak, dan dibutuhkan umat dibungkus dalam kemasan yang menarik, sesuai kemajuan dan perkembangan masyarakat.

Aktivitas dakwah dengan pembaharuan konsep dakwah di media televisi diharapkan mampu melahirkan perubahan yang berarti bagi kemajuan umat dan bangsa. Dakwah harus melahirkan umat yang utama atau umat yang unggul (khairu ummah). Umat yang terbaik adalah umat yang unggul, umat yang aqidah dan ibadahnya kuat. Hal ini dibuktikan dengan melakukan tiga hal yaitu amar mairuf, nahi mungkar, dan iman. Ketiganya dipahami Sayyid Quthub sebagai ciri atau karakter dasar umat Islam. ${ }^{24}$

Kedua, perluasan dan penguatan jaringan/kerjasama dengan lembaga-lembaga yang bergerak di bidang dakwah, dengan paradigma baru yang menekankan pembaharuan dalam perluasan kerjasama dengan lembaga-lembaga dakwah. Dalam hal ini, diharapkan dakwah di televisi semakin bergairah karena dukungan dan kerja sama tersebut. Tanpa dukungan dan kerjasama yang baik dari lembaga dakwah seperti universitas, majelis taklim, dan komunitas däi dan daïah, Badan Kontak Majelis Taklim, Forum Komunikasi Majelis taklim dan seterusnya mustahil dakwah ditelevisi bisa berjalan dengan baik. Hadirnya jamaah dalam kemasan program dakwah di televisi juga memberi nuansa yang baru dalam kemasan dakwah seperti acara "Assalamu’alaikum Ustad" di stasiun RCTI, "Bengkel Hati” di Stasiun TPI, dan "Aa dan Mama Dedeh" di Stasiun Indosiar.

Ketiga, penguatan dana primer dan skunder untuk mendanai program dakwah karena ruh dari penayangan kemasan dakwah di televisi adalah wajib ada dana yang cukup besar. Hal ini mengacu pada "ideologi" industri media massa adalah profit yang tinggi, yang diperoleh melalui produk atau acara yang memiliki nilai jual tinggi, bahasa teknisnya adalah menyesuaikan dengan motivasi khalayak. Dengan begitu, kecenderungan industrial ini sebenarnya bersifat demokratis karena tidak pernah ada program yang dapat disiarkan tanpa bertolak dari motivasi khalayak. Seluruh upaya kreatif berarti membaca motivasi massa untuk kemudian mengemas dalam produk. 
Untuk itu, dakwah haruslah dikemas dengan cara dan metode yang tepat dan pas. Dakwah harus tampil secara aktual, faktual dan kontekstual. Aktual dalam arti memecahkan masalah yang kekinian dan hangat di tengah masyarakat. Faktual dalam arti kongkrit dan nyata. Kontekstual dalam arti relevan dan menyangkut problema yang sedang dihadapi oleh masyarakat. Oleh sebab itu, memilih cara dan metode serta media yang tepat dakwah aktual, faktual dan konstektual menjadi bagian strategis dari kegiatan dakwah itu sendiri, untuk menyajikan kemasan dakwah yang menarik dan menggugah melalui media televisi dengan metode dakwah al-Qư'an surah an-Nahl: 125 perlu diaktualisasikan dalam kemasan televisi. "Serulah manusia ke jalan Tuhanmu, dengan cara hikmah, pelajaran yang baik dan berdiskusilah dengan mereka dengan cara yang baik pula, sesungguhnya Tuhanmua Dialah yang mengetahui siapa yang tersesat dari jalan-Nya dan Dialah yang lebihmengetahui orang-orang yang mendapat petumjuk."

Ayat ini menjelaskan sekurang-kurangnya ada tiga cara atau metode dalam dakwah yakni, metode hikmah, metode maüzah dan metode mujadalah. Ketiga metode dapat dipergunakan sesuai objek yang dihadapi oleh seorang däi atau daiyah di medan dakwahnya. Ada kenyataan yang perlu diperhatikan oleh para aktivis dakwah terutama para crew produksi agama Islam di stasiun televisi dalam mengemas acara dakwah Islam yaitu:

1. Corak kemajemukan (phuralitas) masyarakat Indonesia sebagai suatu bangsa adalah kebhinekaan dalam beberapa aspek kehidupan yang meliputi pandangan hidup (filsafat), sosio kultural, agama, suku, bahasa, dan politik dan sebagainya.

2. Tendensi (kecenderungan) perkembangan masyarakat yang banyak dipengaruhi oleh kemajuan teknologi modern serta ide modernitas yang telah mulai menjiwai trans-pembangunan nasional ke arah perubahan sosial (social change). Nilai-nilai kebudayaan dan agama cepat atau lambat harus dapat secara normatif kultural mengontrol serta menjiwainya.

3. Corak kehidupan psikologis masyarakat modern dan tradisional mengandung ciri-ciri yang menurut sistem pendekatan yang berbeda satu sama lain. Semakin modern suatu kehidupan masyarakat, maka semakin kompleks pula kehidupan psikologisnya dan semakin banyak menuntut sistem pendekatan yang bersifat antarilmu dengan dilatarbelakangi prinsip-prinsip pandangan psikologis yang dalam dan luas. ${ }^{25}$

Kemasan dakwah televisi saat ini hampir semua memakai metode dialog di antaranya seperti: "Hikmah Pagi" di TVRI, "Assalamu 'Alaikum Ustad” di RCTI, “Aa dan Mama” di Indosiar, "Sentuhan Qalbu” di Trans TV, dan seterusnya. Kemasan dakwah di televisi didominasi dialog, walaupun ada perbedaan kemasan, tetapi hanya pada tataran kreatif, misalnya dialognya berbentuk drama keluarga, dan lain-lain. Sekarang ini, angin segar dakwah sudah berkibar di televisi untuk mengimbangi tayangan-tayangan hiburan dan "kemusyrikan" yaitu hadirnya kemasan dakwah dalam bentuk sinetron seperti Rahasi Ilahi di TPI, sinetron Hidayah di Indosiar, dan film-film layar lebar seperti: Ayat-Ayat Cinta, Ketika Cinta Bertasbih, Wanita Berkalung Sorban, dan seterusnya.

Kemudian kemasan dakwah televisi dengan metode monolog misalnya Indonesia berzikir oleh Arifin Ilham di TPI, serta Zikir dan Pengobatan bersama Ustadz Haryono, termasuk metode tabligh dalam kemasan kontes seperti kontes däi dan daïah TPI 2005-2006 dan Pildacil di Lativi dan seterusnya. Ini digemari masyarakat Indonesia, terlebih Indonesia sedang dilanda musibah di laut, darat dan udara, kemudian bencana alam yang beruntun mulai dari gempa, banjir, lonsor dan lumpur panas.

Keempat, hal ini amat penting yaitu peningkatan kualitas dan kuantitas däi dan däiah baik secara moral, akhlak, intelektual, spiritual dan sosial. Seorang däi atau däiah menurut Yusuf Qardhawi harus melengkapi diri dengan tiga senjata, yaitu iman (silah al-iman), akhlak mulia (al-akhlaq al-karimah), dan imu pengetahuan (wawasan). Senjata iman dan akhlak disebut Qardhawi sebagai bekal spiritual, sedang ilmu dan wawasan disebut sebagai bekal intelektual. Oleh karena itu, seorang dai harus melengkapi diri dengan dua bekal, yaitu bekal spiritual dan intelektual sekaligus. Menurut Qardhawi, ada enam wawasan intelektual yang perlu dimiliki oleh seorang dai atau däiah, di antaranya: a). Wawasan Islam meliputi al-Quran, alSunah, fiqih dan ushul fiqh, teologi, tasawuf, dan mizham Islam. b). Wawasan sejarah dari prode klasik, pertengahan hingga modern. c). Sastra dan bahasa. d). Ilmu-ilmu sosial (social sciences) dan humaniora, meliputi sosiologis, antropologi, psikologi, 
filsafat, dan etika. e). Wawasan perkembangan dunia-dunia kontemporer yang meliputi dunia Islam, dunia barat, perkembangan agama-agama dan mazhab-mazhab pemikiran, serta perkembangan pergerakan Islam kontemporer. ${ }^{26}$

Di samping wawasan dan kekuatan intelektual yang ditekankan Yusuf Qardhawi di atas, Sayyid Quthub menekankan tiga kekuatan lain yang juga penting dan wajib dimiliki oleh para däi dan daïah di era globalisasi ini. Pertama, kekuatan moral yang meliputi kasih sayang (rahmah), integritas (muthahaqah bayn al-qawl wa al-fil), kreativitas dan kerja keras. Kedua, kekuatan spiritual meliputi kekuatan ibadah, sabar, dan taqwa. Ketiga, Kekuatan perjuangan (j̈had), meliputi kesaksian däi dan daïah (syahadah), ketahanan menghadapi ujian dan cobaan (al-ibtila), dan kemenangan (al-nashr). ${ }^{27}$

Untuk menyiapkan daii dan däiah dengan kualitas dan kompetensi seperti dikemukakan di atas, para insan akademik dan insan pertelevisian paradigma baru perlu melakukan pengembangan sumber daya manusia, baik melalui jalur pendidikan maupun pelatihan (kaderisasi). Hasilnya adalah dai dan daiah yang berkualitas, kuratif, komunikatif, dan marketable dalam program dakwah televisi. ${ }^{28}$

Mengingat masyarakat Indonesia yang heterogen, maka sebaiknya pembaharuan kemasan program dakwah di media televisi saat ini harus mengacu pada aspek kehidupan psikologis dan sosiologis mad'u yang menyimak siaran dakwah tersebut, diantaranya:

1) Mad'u menyangkut aspek sosiologis berupa masyarakat terasing, perdesaan, perkotaan dan masyarakat daerah marginal dari kota besar;

2) Mad'uyang menyangkut struktur kelembagaan berupa masyarakat, pemerintah dan keluarga;

3) Mad'u yang menyangkut sosial kultural berupa golongan priyayi, abangan, dan santri, terutama pada masyarakat Jawa;

4) Mad'uyang menyangkut tingkat usia berupa kelompok anak-anak, remaja dan orangtua;

5) Mad'u yang menyangkut okupusional (profesi/pekerjaan) yaitu golongan petani, pedagang, buruh, pegawai, dan seterusnya;

6) Mad'u yang menyangkut tingkat hidup sosial ekonomi yaitu kaya, menengah, dan miskin;

7) Mad'uyang menyangkutjenis kelamin (seks) golongan wanita atau pria;

8) Mad'u yang menyangkut golongan khusus seperti pekerja seks komersial, tuna wisma, narapidana dan seterusnya.

Dengan mengacu pada masing-masing golongan masyarakat di atas, däi dan daiiah bersama tim kreatif televisi memerlukan pendekatan dan metode khusus yang mengakomodir aspirasi dan problem masyarakat (mad’u) dalam mengemas dakwah agar bisa diterima oleh semua kalangan secara efektif dan efisien, lebih jauh lagi harapannya adalah pesanpesan dakwah yang siarkan dapat diaplikasikan dalam kehidupan umat.

\section{PENUTUP}

Pesatnya persaingan di dunia televisi menuntut para pelaku dan pemikir dakwah untuk terus meningkatkan kualitas diri dan intelektual dalam melakukan pembaharuan konsep dakwah, memperkuat jaringan kerjasama dan menggalang dana dakwah yang sebesar-besarnya dari berbagai kalangan yang mau menyisihkan hartanya di jalan Allah dalam rangka syiar Islam sehingga dengan leluasa berkreasi mengemas dan memformat dakwah sesuai permasalahan umat ditinjau dari semua aspek kehidupan melalu dakwah di media televisi.

Kekayaan pengetahuan Islam memang memerlukan elaborasi terus-menerus agar tetap aktual dengan kebutuhan zaman. Elaborasi menurut banyak pihak untuk semakin ramah dengan situasi di mana Islam itu hadir, salah satunya adalah dengan memberikan pemaknaan yang lebih luas terhadap dakwah itu sendiri.

Untuk lebih bebas berkreasi dan mengemas dakwah di era globalisasi ini, seharusnya pelaku dakwah tidak hanya bergantung kerjasama dengan pihak pemilik stasiun televisi, tetapi perlu ada televisi komunitas yang berdasarkan/berorientasi dakwah Islam sehingga mampu melakukan pembaharuan dakwah di media televisi tanpa intervensi pihak-pihak yang berkuasa di dunia televisi karena kepentingan komersialisasi semata. 


\section{ENDNOTE}

1. Sejak krisis nasional dan internasional hingga sekarang, banyak timbul dalam masyarakat berbagai penyimpangan agama yang mengganggu kemumian aqidah, antara lain munculnya paham nativisme yang berarti asal atau asli. Nativisme menunjuk pada paham asli atau paham lama sebelum datang Islam yang meyakini kekuatan-kekuatan lain selain Allah SWT. Paham ini kini muncul lagi dan merebak kembali di masyarakat.

${ }^{2}$ Komarudin Hidayat, "Agama dan Kegalauan Masyarakat Modem", dalam Nurcholish Madjid, Kehampaan Spiritual Masyarakat Modem, (Jakarta: Mediacita, 2000), hal. 101. Modemisme memiliki dua wajah, positif dan negatif sekaligus. Oleh karena itu, modemisme mendapat julukan "abad ilmu pengetahuan dan teknologi" (The Age of Science and Technology) dan "abad kecemasan" (The Age of Anxiety). Lihat Hanna Jumhana Bastaman, "Makna Hidup bagi Kehidupan Modem Tinjauan Psikologis" dalam Muhammad Wahyu Nafis, Rekonstruksi The Modem World, Religius Islam (Jakarta: Paramadina, 1996), hal. 144.

${ }^{3}$ Syekh Ali Mahfudz, Hidayat al-Mursyidin ila Thunuq al-Wa'zh wa al-Khithabah (Beinut: Dar al-Marifah, TT), hal. 6.

${ }^{4}$ Everett M Rogers, Communication Technology, The New Media in Society (London: The Free Press Collier Macmillan Publisher, 1986), hal. 25.

${ }^{5}$ Harrison B. Summer, RobertE. Summer, and John H., Broadcasting and the Public (Balmont: Woodsworth Publishing Company, Inc., 1978).

${ }^{6}$ Ashadi Siregar, Menyingkap Media Penyiaran, Membaca Televisi Melihat Radio(Yogyakarta: LP3Y, 2001), hal. 108.

${ }^{7}$ Ashadi Siregar, Menyingkap Media Penyiaran, hal. 109.

${ }^{8}$ Onong Uchjana Effendy, Televisi Siaran Teori dan Praktik (Bandung: Mandar Maju, 1993), hal. 21.

${ }^{9}$ Everett M Rogers, Communication Technology, The New Media in Society (London: The Free Press Collier Macmillan Publisher, 1986), hal. 25.

${ }^{10}$ Burhan Bungin, Pomomedia (Konstruksi Sosial Teknologi Telematika dan Perayaan Seks di Media Massa) (Jakarta: Kencana, 2003 ), hal. 18.

${ }^{11}$ Ashadi Siregar, Menyingkap Media Penyiaran, hal. 76.

${ }^{12}$ Onong Uchjana Effendy, Televisi Siaran Teori dan Praktek, hal. 24.

${ }^{13}$ Ashadi Siregar, Menyingkap Media Penyiaran, hal. 4.

${ }^{14}$ Peter Salim dan Yenny Salim, Kamus Bahasa Indonesia Kontemporer(Jakarta: Modem English, 1999), hal. 1095.

${ }_{15}^{15}$ Depdikbud, Kamus Besar Bahasa Indonesia (Jakarta: Balai Pustaka, 1998), hal. 648.

${ }^{16}$ Save M.Dagun, Kamus Besar Lima Pengetahuan (Jakarta: Lembaga Kebudayaan Nusantara, TT), hal. 777.

${ }^{17}$ Aep Kusnawan, Komunikasi Penyiaran Islam (Bandung: Benang Merah Press, 2004), cet. ke-1, hal. vii.

${ }^{18}$ lbid., hal. viil.

${ }^{19}$ Tabligh merupakan suatu penyebarluasan ajaran Islam.

rolrsyad ialah penyebarluasan ajaran Islam.

${ }^{21}$ Tadbirialah sosialisasi ajaran Islam.

${ }^{2}$ Tathwirialah sosialisasi ajaran Islam.

23llyas Ismail, Paradigma Dakwah Sayyid Qutub: Rekonstruksi Dakwah Harakah (Jakarta: Penamadani, 2006), hal. xxvii.

${ }^{24} /$ bid., hal. 141.

${ }^{25}$ H.M. Arifin, Psikologi Dakwah (Jakarta: Bumi Aksara, 1991), hal. 2.

${ }^{26}$ Yusuf Qardhawi, Tsaqafat al-Dailyah (Beirut al-Mu'assasah al-Risalah, 1979), hal. 1-144.

${ }^{27}$ llyas Ismail, Paradigma Dakwah Sayyid Qutub: Rekonstruksi Dakwah Harakah.

\section{DAFTAR PUSTAKA}

Bungin, Burhan. 2003. Pomomedia: Konstruksi Sosial Teknologi Telematika dan Perayaan Seks di Media Massa. Jakarta: Kencana. Depdikbud. 1998. Kamus Besar Bahasa Indonesia. Jakarta: Balai Pustaka.

Effendy, Onong Uchjana. 1993. Televisi Siaran Teori dan Praktik. Bandung: Mandar Maju.

Kusnawan, Aep. 2004. Komunikasi Penyiaran Islam. Bandung: Benang Merah Press.

M. Arifin. 1991. Psikologi Dakwah. Jakarta: Bumi Aksara.

M. Dagun, Save. TT. Kamus Besar Lima Pengetahuan. Jakarta: Lembaga Kebudayaan Nusantara.

Madjid, Nurcholish. 2000. Kehampaan Spintual Masyarakat Modem. Jakarta: Mediacita.

Mahfudz, Syekh Ali. TT. Hidayat al-Mursyidin ila Thuruq al-Wa'zh wa al-Khithabah. Beirut: Dar al-Marifah.

Nafis, Muhammad Wahyu. 1996. Rekonstruksi The Modem World, Religius Islam. Jakarta: Paramadina.

Qardhawi, Yusuf. 1979. Tsaqafat al-Daiyah. Beinut: al-Mu'assasah al-Risalah.

Rogers, Everett M. 1986. Communication Technology, The New Media in Society. London: The Free Press Collier Macmillan Publisher. Salim, Peter dan Yenny Salim. 1999. Kamus Bahasa Indonesia Kontemporer. Jakarta: Modem English. 
Siregar, Ashadi. 2001. Menyingkap Media Penyiaran, Membaca Televisi Melihat Radio. Yogyakarta: LP3Y.

Summer, Harrison B. dan John H. 1978. Broadcasting and the Public. Balmont: Woodsworth Publishing Company, Inc. 